\title{
MANAGING THREATS TO FRESHWATER SYSTEMS WITHIN PROTECTED AREAS
}

J. Pittock ${ }^{1}$, L. Baumgartner ${ }^{2}$, C.M. Finlayson ${ }^{3}$, J.D. Thiem ${ }^{4}$, J.P. Forbes ${ }^{2,4}$, L.G.M. Silva ${ }^{2}$ and A.H. Arthington ${ }^{5}$

${ }^{1}$ Fenner School of Environment and Society, The Australian National University, Australia

${ }^{2}$ Institute for Land, Water and Society, Charles Sturt University, Australia

${ }^{3}$ Institute for Land, Water and Society, Charles Sturt University, Australia \& Institute for Water Education, UNESCO-IHE, Delft, The Netherlands

${ }^{4}$ Department of Primary Industries, Narrandera Fisheries Centre, Australia

${ }^{5}$ Australian Rivers Institute, Griffith University, Australia

Key messages

Freshwater and estuarine ecosystems are among the most threatened in the world, are underrepresented in protected areas policy and have the highest portion of species threatened with extinction.

Freshwater biodiversity is particularly threatened because its conservation depends on: maintaining hydrological processes; retaining longitudinal connectivity of water flows without barriers along rivers; conserving lateral connectivity between a water body and its floodplain; sustaining adequate groundwater-surface water interactions; managing exogenous threats that are propagated across catchments; and integrating governance by multiple management authorities. The impacts of agriculture, aquaculture and fishing need to be managed.

Where protected areas are established particular attention should be given to: minimising impacts of water infrastructure, invasive species incursion control; reducing impacts of visitor facilities and activities, and pollution prevention.

Floods, droughts and fire are natural processes in many freshwater ecosystems and plants and animals can normally tolerate or recover from them. However, these processes are exacerbated by climate change leading to changes in ecological character. In different circumstances freshwater ecosystems may attenuate or increase the impacts of natural disasters on people.

Introduction: Threats to freshwater ecosystems

Freshwater and estuarine ecosystems are among the most threatened in the world, with the Millennium Ecosystem Assessment describing freshwater ecosystems as being over-used, underrepresented in Protected Areas (PAs) and having the highest portion of species threatened with extinction (Millennium Ecosystem Assessment 2005). People and societies worldwide have 
inextricable links to freshwater ecosystems, and both people and nature benefit by managing risks to the health of these habitats (Dudgeon, Arthington et al. 2006, Vörösmarty, McIntyre et al. 2010). Primary direct drivers of degradation and loss of riverine and other wetlands include land conversion, infrastructure development, water withdrawal, pollution, over-harvesting and overexploitation of freshwater species, the introduction of invasive alien species, and global climate change (Millennium Ecosystem Assessment 2005, Dudgeon, Arthington et al. 2006). The World Commission on Protected Areas outlines how freshwater biodiversity is particularly threatened because its conservation depends on the following factors (Dudley 2013):

- Maintaining hydrological processes;

- Retaining longitudinal connectivity of water flows without barriers along rivers;

- Conserving lateral connectivity between a water body and its floodplain;

- Sustaining adequate groundwater-surface water interactions;

- Managing threats that are propagated in catchments and transmitted to inland waters at the lowest points on the landscape;

- Integrating governance by multiple management authorities.

- Developing policies to establish protected areas capable of sustaining the health and integrity of freshwater ecosystems.

This initial section on threats is focused on those that managers need to address within PAs, whereas later sections provide advice on managing threats at the landscape scale. A particularly concise source of information for managing wetlands in PAs to avoid or mitigate these threats is Wetland management planning: A guide for site managers (Chatterjee, Phillips et al. 2008). The resolutions and guidelines of the Ramsar Convention and the Ramsar handbooks for the wise use of wetlands (Ramsar Convention Secretariat 2010) provide excellent advice on good international practices for almost any wetland management challenge. Finlayson (2013) provides an analysis of how the wise use principles of the Convention relate to the threats raised by climate change. Management of a number of specific anthropogenic threats common to freshwater ecosystems within PAs are discussed here.

Water infrastructure and diversions

Freshwater, food and energy are inextricably linked on a global scale. Freshwater is essential for potable supply, producing food and agricultural products, for supporting subsistence communities, and to harness "renewable" energy. Yet human development of freshwater systems has been inequitable. Eleven percent of the global population are still without access to clean water, sanitation, food resources or modern energy. To redress this inequity, humans are transforming the riverine environment and exploiting natural resources at an unprecedented rate. By 2050 , it has been estimated that the world will require $70 \%$ more agricultural production (Bruinsma 2011) and, by 2035, 50\% more primary energy (de Fraiture, Wichelns et al. 2007). To meet these demands irrigated agriculture will need to be extended (Döll 2002) and hydropower development is expanding at $1500 \%$ per annum; not expected to peak until 2030 (Zarfl, 
Lumsdon et al. 2015). Irrigation and hydropower network expansion is therefore inevitable for most freshwater systems throughout the world (Ellis 2011). The resultant situation will be increased conflict over limiting resources, and degradation of freshwater environments, unless appropriate steps are taken to improve outcomes on a global scale.

The global expansion of irrigation and hydropower challenges the long-term sustainability of the historically productive freshwater systems; upon which many people depend for income and food, and contribute substantial biodiversity globally. Activities in catchments (e.g. vegetation removal, land conversion), water infrastructure, flow regulation, diversions and inter-basin transfers (IBTs) alter flows that are vital to maintain freshwater biodiversity, change habitats from riverine to lacustrine and disrupt connectivity to the point where physical and biological processes are substantially disturbed (Poff, Allan et al. 1997).

Catchment wide planning is essential to sustain water for the environment (see upcoming section; Arthington et al., (2017). The worst impacts of dam developments on freshwater may be reduced through appropriate basin-wide planning that seeks to locate new water infrastructure at sites that minimise environmental and social impacts while providing the desired economic benefits (Winemiller, McIntyre et al. 2016). For example, it may be possible to fully develop dams on already damaged river tributaries while retaining connectivity and natural flow variability on other tributaries or the main stem of a river. This requires assessment to be undertaken at a large scale before individual dams are approved. Freshwater PA managers should promote such processes by their governments where new developments are proposed. In the Mekong River basin there are examples of strategic environmental assessment (ICEM 2010) and a sustainability assessment tool (MRC 2010) to inform such decisions, which sadly in that case, have not been used to date. The guidelines of the World Commission on Dams (WCD 2000) and the industry endorsed Hydropower Sustainability Assessment Protocol (IHA 2010) provide further tools that can be used to advocate for better environmental outcomes from water infrastructure development.

Major water storage dams are often located within nature reserves. Many of these were built over the objections of protected area managers. For example, the Hetch Hetchy Reservoir was built in Yosemite National Park in 1913-23 (Righter 2005). In an era of increasing water scarcity more proposals to exploit water resources within nature reserves are certain. These developments should be resisted to prevent damage to freshwater biodiversity, but if imposed on protected area managers the mitigation measures described below should become mandatory. While this discussion has focussed on surface waters, the conservation of groundwater systems and dependant ecosystems requires similar vigilance in the face of increasing water extraction.

Where surface water diversions or infrastructure are proposed or in place, five key measures will reduce but not fully compensate for the impact on freshwater ecosystems and the conservation of aquatic species (Davies, Harris et al. 2010, Pittock and Hartmann 2011): restoration of fish passage around dams, especially for migratory fish species and other mobile taxa; provision for 
release of environmental flows that mimic natural river flows (see upcoming section, and Arthington et al. (2017); building dam outlet structures that can eliminate downstrem thermal pollution (Rolls, Growns et al. 2013); and conservation and restoration of the river corridor below the dam, for example, by restoring riparian vegetation and strategically placing infrastructure in areas that will minimise impact from the outset. Screening water diversion intakes to prevent loss of fish and other aquatic wildlife may also help (Ghassemi and White 2007, Baumgartner, Reynoldson et al. 2009).

Many protected area managers have installed small dams, either to supply protected area managers and visitors with a potable water supply or to enhance water security for wildlife and wildlife viewing, as in Kruger National Park (Brits, Van Rooyen et al. 2002). To reduce the ecological impacts of water supply infrastructure for people in PAs, it would be preferable to access groundwater sustainably or rely on off-river storage tanks or small dams. Establishing water storages along river corridors for wildlife is a misguided notion that should only be considered in exceptional circumstances, such as part of a targeted threatened species recovery plan. Even small dams across streams can block the passage of aquatic wildlife and reduce their populations. There are also negative impacts on terrestrial and riparian ecosystems, for instance, by enabling concentration and overgrazing by herbivores.

Wherever possible, redundant water storages within PAs should be decommissioned, as is occurring in Kruger National Park. There are a number of manuals available to guide removal of dams (Lindloff 2000, Bowman 2002). For example, in the United States two large dams are being removed on the Elwha River to enable migratory salmon to recolonize habitat within Olympic National Park (Howard 2012). This dam removal project, the largest in US history, reopens $>100 \mathrm{~km}$ of spawning and rearing habitat for five species of salmonids in the Elwha River and its tributaries. "Elwha chinook - the largest salmon in the river and unique in Puget Sound - cruised right past the former Glines Canyon Dam site just three days after it was blown out of their way" (Mapes 2016).

Water infrastructure does not last forever, as it progressively degrades and needs to be removed, repaired or replaced (Krchnak, Richter et al. 2009). As climate change alters the hydrological parameters that water infrastructure was designed to operate within a lot of these structures need to be re-operated or even decommissioned (Pittock and Hartmann 2011). Re-operating water infrastructure is an opportunity to apply higher environmental standards that may have been adopted since first construction, such as by adding sediment flushing, thermal pollution control, fish passage and environmental flow release valves. Beyond water infrastructure, the additional threats from agriculture are now considered.

Agriculture

Agriculture and aquaculture are often excluded from IUCN category I to IV PAs because they are regarded as intensive commercial activities inimical to biodiversity conservation. These industries 
are included in the discussions of this book on conservation and management of freshwater PAs for two reasons. First, human settlements are often focussed around freshwater ecosystems which have been and continue to be used by people. Many freshwater ecosystems are cultural landscapes shaped by the activities of people over millennia such that maintaining traditional practices, including agriculture and aquaculture, is required to sustain biological and other values. Further, conservation of representative areas of freshwater ecosystems in PAs requires use of a full range of IUCN PA categories, so as to include those areas that remain heavily used by people. Second, agriculture and aquaculture occupy increasing areas around and within freshwater PAs, so their impacts need to be managed to maintain freshwater ecosystem integrity.

Agricultural practices over the past few centuries have caused wide-scale changes in land cover, watercourses, and aquifers, contributing to the loss and degradation of wetlands and undermining the ecological processes that support the provision of a wide range of ecosystem services (MEA 2005, Dixon, Wood et al. 2008, Boelee, Scherr et al. 2013). Among these are reductions in provisioning ecosystem services such as the supply of fresh water and fisheries, reduced regulating services such as storm protection and nutrient retention, and the loss of cultural services such as spiritual and recreational values. This has occurred as many agricultural systems have been managed as if they were not connected with the wider landscape, including the rivers and floodplains that have been so important for maintaining the ecological processes that have underpinned their sustainability (Falkenmark, Finlayson et al. 2007, Gordon, Finlayson et al. 2010). Irrigation and drainage of landscapes, the extensive clearing of vegetation, and the addition of agro-chemicals (fertilizers and pesticides) have altered the quantity and quality of water in the landscape. Modifications of water flows and water quality having major ecological, economic, and social consequences, as well as impacts on human well-being, for example, through insect-borne disease or through changes in nutrition (Horwitz and Finlayson 2011).

Agriculture threatens freshwater biodiversity in many ways, including: conversion of habitat, degradation of riparian vegetation, development of water infrastructure, diversion and regulation of water flows, grazing of vegetation by livestock, soil and bank erosion, pollution from farm chemicals, and introduction of alien species. Examples of the cropping systems that generate numerous ecological impacts include cotton and sugar production in Australia (Arthington 1996, Arthington, Marshall et al. 1997). Riparian degradation has many implications for stream ecosystems, including alterations to shading and the thermal characteristics of streams, the failure of diminished vegetation to intercept runoff and filter sediments and nutrients, loss of bank stability, erosion and sedimentation, degraded aquatic habitats and reduced energy subsidies (Pusey and Arthington 2003). The measures described above for conserving riparian corridors, providing environmental flows, screening water intakes and preventing pest species introductions are important to mitigate the many impacts of agriculture.

All too often the consequences of modifying agricultural landscapes have not been fully considered nor adequately monitored. In some instances agricultural practices have caused some ecosystems, such as inland lakes, to pass ecological tipping points, leading to a regime change in the ecosystem 
and the loss of important ecosystem services and benefits for local people. However, strong lines of evidence to support many claims of changes of wetlands passing tipping points have not been supported by long-term monitoring (Capon, Lynch et al. 2015). Despite issues with evidence and understanding of the consequences of changes in wetlands due to agriculture Falkenmark et al. (2007) have questioned whether or not we have gone too far in developing agriculture at the expense of the many benefits that wetland ecosystems can provide, especially in terms of how we have changed water flows and disposed of waste products. The answer to this question is dependent on many factors and local circumstances and is influenced by history as well as changing climates and changes in agricultural practices and the human demands for food.

An overview of wetland distribution, type and condition across Sub-Saharan Africa highlighted the reliance of local communities on wetland agriculture and showed that the nature of household dependence varied significantly from place to place and with socio-economic status (Rebelo et al. 2010). Consequently, measures to manage agriculture in wetlands will need to differ markedly from one location to another and across socio-economic groups. Rebelo et al. (2009) also reported that $78 \%$ of wetlands listed as internationally important in 2006 under the Ramsar Convention supported agricultural activities, with $80-90 \%$ of sites in forest and savanna biomes containing agriculture; and more than 50\% in other biomes. Nagabhatla et al. (2010) noting the limits of the available data reported an increase in wetlands under cultivation increased from $25 \%$ in 1926 to $43 \%$ in 2006. Such figures demonstrate the importance of wetlands for agriculture and highlight how agriculture has very likely shaped the character of many wetlands, in some cases over long time periods. The duality of agriculture being a major cause of wetland loss and degradation as well as shaping the very character of remaining wetlands provides a dilemma for future wetland management.

Land clearing and more intense land uses as well as increased water regulation and diversion of water away from riverine systems is now widespread and prompted Davis et al. (2015) to examine "the challenge of protecting freshwater ecosystems under multiple land use and hydrological intensification scenarios" in Australia's Murray-Darling Basin. Their study highlighted the importance of managing and improving water quality, the value of providing environmental flows within a watershed framework, and the significant role that innovative science and adaptive management must play in developing proactive and robust responses to intensification. Research priorities to support improved governance and management include: i) determining the relative contributions of surface water and groundwater in supporting freshwater ecosystems in agricultural landscapes; ii) identifying and protecting freshwater biodiversity hotspots and refuges; iii) improving our capacity to model hydro-ecological relationships and predict ecological outcomes from land use intensification and climate change; iv) developing an understanding of long term behaviour of riverine ecosystems; and v) exploring systemic approaches to enhancing governance systems, including planning and management systems affecting freshwater outcomes. They also saw the integration of land and water management as essential. 
The dilemma is all the more important as it has been estimated that by 2050 food demand will double with an expected increase in the demand for water for irrigated agriculture. In a simple sense the increased demand for water could be met through increased water use on current agricultural lands, or an expansion of agricultural lands, or through increased water productivity, each with different implications for wetland ecosystems. While all are plausible outcomes it is expected that a mix of solutions is likely (Falkenmark, Finlayson et al. 2007). Dependent on local conditions and the further adoption of existing and new technologies both agricultural and wetland management practices will need to be substantially improved to reduce the impacts from agriculture, whether within wetlands or on other lands. Further intensification of agriculture could lead to further water pollution, while expanding agriculture will require careful management to prevent further degradation and loss of ecosystem services. In some cases there have been efforts to reverse the loss and degradation of wetlands through rehabilitation and, in some cases, full restoration, although this is likely to be expensive, if possible at all. The latter is an important consideration as some changes can be nearly irreversible, for example, changes in ecological regimes in inland freshwater lakes (Capon, Lynch et al. 2015). These changes can occur suddenly, although they often represent the outcome of a slow decline in wetland (lake) ecosystem integrity and reduced ecological resilience that undermine the ability of the ecosystem to retain the same function, structure and feedbacks even when the pressure is reduced.

Failure to tackle the loss and degradation of wetlands, including that caused by the development and management of agriculture and related water resources, will undoubtedly undermine progress toward achieving the UN Sustainable Development Goals of reducing poverty, and hunger, and increasing wetland sustainability. An integrated approach to wetland management at a catchment scale is needed to halt past trends and restore, where possible, essential ecosystem services, especially where local communities are dependent on these services. This includes making decisions on the trade-offs that have occurred where agriculture has affected wetlands and occurs within wetlands. These should be based on a set of alternative scientifically informed scenarios, supported by social and economic analyses, as outlined in the guidance provided by the Ramsar Convention for the wise use of wetlands (Finlayson, Davidson et al. 2011). To date such guidance has proven difficult to implement given political decisions, such as those outlined in plans to restore wetlands in Australia's Murray-Darling Basin, that are unlikely to sufficiently address the degradation caused by past agricultural practices and misguided agricultural policies (Pittock and Finlayson 2011). As well as sound science, ongoing attention is needed to communicate ecological process understanding across disciplinary and sectoral boundaries and to relevant policy and decision-makers.

In view of the huge scale of future demands on agriculture to feed people and eradicate hunger, and the past undermining of the ecological functions on which agriculture depends, Falkenmark et al. (2007) have highlighted the essential need to change the way we have been doing business. To achieve this, we need to: 
- Address social and environmental inequities and failures in governance and policy as well as on-ground management.

- Rehabilitate degraded ecosystems, and, where possible, restore lost ecosystems.

- Develop institutional and economic measures to prevent further loss and to encourage further changes in the way we do business.

- Increase transparency in decision-making about agriculture-related water management and increase the exchange of knowledge about the consequences of these decisions.

The growing number of agricultural sustainability certification programs, including the Water Stewardship Standard (AWS 2014), offer the prospect of recognising and rewarding better practices in agriculture that reduce the industry's impacts on freshwater ecosystems.

Fishing and over harvesting

Although PAs are usually designated to protect wildlife, in many societies fish and other harvested aquatic species are not afforded the same level of legal protection as a mammal might receive. Further, many fish species are migratory at some point in their life cycle and are thus vulnerable to harvesting outside PAs and may have life stages dependent on accessing critical habitat elsewhere (Arthington, Dulvy et al. 2016). For these reasons managing the threats from over harvesting aquatic species are discussed here.

Over-harvest is one of the greatest threats to wild freshwater fish stocks globally, especially considering that freshwater fish contribute $15.3 \%$ of total animal protein consumed by people globally (Tacon and Metian 2008). It is further estimated that 1 billion people are involved in freshwater fisheries supply chains - processing, packing, transport and retailing (Allan, Abell et al. 2005). Some freshwater fisheries are highly productive. For example, the annual freshwater fish harvest from the Lower Mekong Basin comprises $2 \%$ of the total global fish harvest (Hortle 2007). Hoever, for almost all fisheries worldwide, harvest rates are unsustainable. An increasing demand for resources linked to an expanding global population and improvements in the efficiencies of fishing gears have led to a situation where overfishing is a major cause of global freshwater fish extinctions (Allan, Abell et al. 2005).

Several types of fishing activity that are commonly deployed include commercial, subsistence (or artisanal), recreational (or sport) and illegal (Abell, Allan et al. 2007). Commercial fishing is the catch and re-sale for economic gain. It is generally perceived to have greater impacts than other forms because high yields can quickly deplete fish stocks and threaten extinction (Pauly, Christensen et al. 2002). Subsistence fishing refers to harvest primarily for consumptive purposes. Subsistence fishing is often unregulated because of household reliance as a source of income, protein and micronutrients (Panayotou 1982). Recreational fishing occurs globally for either harvest, or as catch and release. It can occupy many forms, deploying many gear types and is often species-specific (Cooke, Arlinghaus et al. 2015). Illegal fishing may comprise any form but in general refers to any fishing that occurs in contravention to established laws, cultures and 
regulations (Sullivan 2002). Each method or approach has different impacts, and can rapidly deplete the resource base if left unregulated or unmanaged.

The impacts of fishing can be limited in a variety of different ways. Commercial fisheries may have gear restrictions or harvest quotas (Pauly, Christensen et al. 2002). Subsistence fisheries may be regulated by community co-management frameworks (Panayotou 1982). Recreational fisheries are controlled via harvest restrictions such as size or bag limits as well as seasonal closures to protect sensitive life history events such as spawning aggregations, parental care, etc (Forbes, Watts et al. 2015). Illegal fishing is generally combated using strong compliance frameworks, although there is evidence that non-mandated regulations can also be effectively applied (Cooke, Suski et al. 2013). Irrespective of the control method, the overall goal of fisheries management is to reduce stress on the resource and ensure harvest occurs at sustainable levels over the long term (Pauly, Christensen et al. 2002). Thus, in the context of fisheries sustainability, management strategies in protected areas should focus on establishing zones or locations where one or more types of fishing are restricted or outlawed.

Many examples of freshwater protected areas have been established specifically to protect fish from exploitation. However, a major deficiency in protected area policy is that regulations are limited, often permitting fishing by a sub-set of methods or by imposing temporary restrictions. For instance, special rights are often granted to recreational fishers in many areas of the world under the assumption of minimal or no impact to the target or non-target species. For example, downstream of Yarrawonga on the Murray River, Australia, the nationally endangered trout cod (Maccullochella macquariensis) is protected by a complete ban on harvest by any method, but fishing for other species is permitted in the protected zone. Trout cod often comprise unwanted by-catch and therefore endure unquantified post-release mortality or physiological impairment. Similarly, the Pacaya-Samiria National Reserve (Peru, South America) was established to protect migratory fish (specifically Arapaima gigas). The freshwater reserve is hailed as a conservation success as netting is completely prohibited in the region. However, the ban has given rise to a strong sports fishery. Many thousands of tourists fish the region annually in hope of catching an Arapaima, which can exceed $100 \mathrm{~kg}$. From a long term perspective, large-bodied freshwater species are at the greatest risk of extinction from over-harvest due to small numbers and lower growth rates compared to smaller fish (Allan, Abell et al. 2005). However, this is seldom formally recognised in any PA planning processes. The broader conservation impacts of sustained harvest are seldom considered significant in the context of PA planning.

A key to preventing overharvest of fish in protected areas is recognising that the place of capture may only represent a snapshot of a fish's life and the habitats it occupies (Fausch, Torgersen et al. 2002). It is important to recognise that the majority of fish are migratory (Schlosser and Angermeier 1995). For long lived species, the requirement to move long distances risks exposure to multiple threats over many years (Baird 2006). The challenge for freshwater PAs is to recognise this diversity of life history strategies and ensure that fishing regulations are 
implemented simultaneously with a range of other management interventions, such as habitat protection, sustainable infrastructure and water management, over longer timeframes.

Threats from aquaculture

Fish, and other freshwater organisms, account for $72.4 \%$ of all capture harvest in developing countries (Diana 2009). Increasing global human populations are therefore driving a sharp decline in freshwater resources (Tidwell and Allan 2001). Options that can augment wild production, such as aquaculture or aquaponics, are increasingly seen as a mechanism to reduce pressure on wild stocks. Aquaculture is generally defined as the farming of fish, shellfish, or aquatic plants and production practices vary accordingly. Aquaculture techniques are being developed for fish, molluscs, crustaceans and plants. It is a fast-growing industry aimed at addressing predicted global food shortages (Naylor, Williams et al. 2001). In 2008, 60\% of the world aquaculture production was occurring in freshwater systems (Bostock, McAndrew et al. 2010). It is expected the aquaculture industry will continue to grow significantly until 2025 (Diana 2009).

Most aquaculture ventures are either pond-based, where animals are bred and grow in isolated systems, or cage-based, where animals are reared and fed in pens in open waterways. Growing freshwater aquaculture trends include methods to improve intensification and cost-effectiveness with the development of new bio-engineering technologies and genetic fish strains with high growth rates and meat yield (Bostock, McAndrew et al. 2010). High intensity production of economically important species can alleviate stress on wild fish stocks, provide employment opportunities for local people (Diana 2009) and, in a few cases, with species introduction providing desirable ecosystem functions (Schlaepfer, Sax et al. 2011). However, a precautionary approach is required to analyse any possible benefits of species introduction (Vitule, Freire et al. 2012) and can also provide a mechanism for conservation re-stocking of wild stocks under enormous pressure. Under such scenarios, especially where aquaculture is a cultural activity that has persisted for many generations, encouraging such practices within protected areas may provide substantial benefits to communities.

In general, however, the more intense the operation is, the higher the negative impact on freshwater systems. The predominant negative impacts include water quality deterioration which arises from uneaten food, surplus chemical supplements and waste discharge (Diana 2009). Freshwater finfish, such as tilapias, are often grown in closed systems, such as inland ponds and increasingly in floating cages in open water bodies from which escapes are inevitable (McCrary, van den Berghe et al. 2001). Aquaculture species frequently establish reproducing populations when they escape from the aquaculture system into suitable habitats or are introduced into the wild (Arthington and Blühdorn 1996), and many have a history of rapid spread (Canonico, Arthington et al. 2005). Escape from cages is a significant issue, especially when culture of nonindigenous species occurs on large scales (Gozlan, Britton et al. 2010). In many areas, escape from aquaculture has led to the proliferation of many non-native species, especially carp 
(Cyprinus carpio) and tilapia (Oreochromis spp) (Weber and Fausch 2003, Cooke and Cowx 2006). High density production can also lead to substantial disease outbreaks (McGinnity, Prodöhl et al. 2003).

The main means to minimise aquaculture impacts are either mechanical or operational. For instance, improved production techniques and holding technology, as well as sound management programs, can generally minimise risk. Treating aquaculture ponds prior to, and post, harvest can substantially improve water quality outcomes (Lin and Yi 2003). The development of reproductively-inert triploid-strains of species can minimise the chance of aquaculture fish breeding with wild populations (Cotter, O'Donovan et al. 2000). The use of wild fish, to feed farmed fish, can be reduced by developing alternative and novel food sources (Naylor, Goldburg et al. 2000).

Aquaculture impacts can also be mitigated through strong policy development (Naylor, Goldburg et al. 2000). Negative examples of policy development for aquaculture have been described in Brazil (Pelicice, Vitule et al. 2014). Obviously the most effective way to mitigate aquaculture impacts is to disallow it completely, but then positive benefits will not be realised. A pragmatic way forward is to establish oversight groups which can regulate or provide stewardship for the industry (Bush, Belton et al. 2013). For example, in Australia, the establishment of an Aquaculture Stewardship Council led to improved industry standards. The Council was instrumental in helping to develop a hatchery quality assurance scheme (HQAS) which clearly specifies the obligations of aquaculture operators and outlines acceptable procedures; all of which were supported by strong research and development programs (New South Wales Department of Primary Industries 2008). Advisory groups can also help to create aquaculture development zones which set boundaries for the production of certain species in the context of potential economic returns and likelihood to minimise impacts on the surrounding environment (Tidwell and Allan 2001).

Aquaculture will be a dominant feature of the freshwater landscape in coming years. The future challenge is to find a balance between the negative and positive impacts of aquaculture (Diana 2009). Where aquaculture is permitted in protected areas, the combination of sound operational practices, and the development and implementation of robust policy, is needed to ensure impacts are minimised and positive outcomes are generated.

Invasive species

The growth in global transport and communication vectors is increasing the ability of alien species to move to new habitats and become invasive (Canning-Clode 2015). Vectors include movement of species by air, ships ballast water, overland transport and internet mail order deliberately or incidentally to agriculture, aquaculture escape, international development, interbasin water transfer, tourism, gardening, aquarium pet escapes, biological control and scientific research endeavours. Once species have invaded they may significantly change ecological 
processes, including the generation of ecosystem services for people (Vilà and Hulme 2017). Both the Convention on Biological Diversity and Ramsar Convention on Wetlands have adopted resolutions urging all governments to adopt a precautionary approach to movement of alien species (CBD 2002, Ramsar 2002).

Alien animal and plant species once introduced into natural water bodies are particularly difficult to eliminate or manage. Unintentional introductions of aquatic species occur through ballastwater discharge from shipping, bait-bucket releases by anglers, and escapes from the ornamental fish trade, fish farms and ornamental ponds (Canonico, Arthington et al. 2005). Invasive fish species threaten native taxa by predation, competition, habitat alteration, hybridization and the transfer of parasites and diseases (Strayer, 2010). Several species of the mosquitofish Gambusia (Poeciliidae) introduced deliberately for biocontrol of pest mosquitoes in many countries threaten native fish species in numerous freshwater habitats, including PAs, by preying on eggs, competition for food and aggressive behaviour (Pyke 2008). Deliberate sport fish introductions threaten native species, especially when the alien species are top predators, such as bass (Centrarchidae) and trout (Salmonidae). The zebra mussel (Dreissena polymorpha), a prohibited invasive species native to Eastern Europe and Western Russia, entered the US Great Lakes in ship's ballast, with devastating consequences for native American unionid clams, ecosystem functions (e.g. foodweb structure), and human uses of these waterbodies for fishing and recreation (Schloesser and Nalepa 1994, Strayer 2010).

Where invasive species are present in a country, distribution modelling can guide the design of efficient species-specific monitoring programs to forecast future distributions and prevent invasions from adjacent river basins. Model outputs can also be used in developing regional freshwater conservation plans (e.g. (Esselman and Allan 2011).

A stepwise process is needed to prevent alien introductions and translocations and control those that do occur (Chatterjee et al, 2008):

- Identify local vectors for introduction of species (e.g. aquaculture farms, ornamental gardens) and seek voluntary or regulatory measures to prevent pest releases;

- Monitor freshwater ecosystems to identify new, problem species, drawing on information on pest species in your country or region that may invade;

- Eliminate newly observed populations of threat species - incursion management;

- Prevent the spread of pest species (this may be a case where a barrier dam in a stream serves to protect upstream populations of indigenous species from alien species spreading from downstream);

- Institute control measures where they are feasible.

Confounding the challenge of managing invasive species is the potential impact of climate change on distributions of indigenous freshwater species (Daufresne and Boet 2007). This raises questions for freshwater PA managers of which species are acceptable and which ones are likely 
to become invasive and problematic. Novel ecosystems are emerging under shifting climatic regimes and will require new approaches to identify, value and conserve freshwater biodiversity (Catford, Naiman et al. 2012, Finlayson, Capon et al. 2017). There is a particular threat of expansion of invasive freshwater species due to climate change, resulting in a decline in populations of native species (Rahel, Bierwagen et al. 2008). Greater control over vectors such as inter-basin water transfers and recreational use of water bodies are two measures required to limit the spread of alien species in a changing climate.

\section{Recreational use of water bodies}

Freshwater ecosystems are a magnet for a wide range of recreational users and activities. International tourism represented 7\% of global exports in 2015 and tourist arrivals are expected to increase by $3.3 \%$ per year to 2030 (UNWTO 2016). While this section focuses on the management of the impacts of recreation on freshwater protected areas, access to healthy freshwater ecosystems is also critical driver for tourism that sustains protected area systems. For example, research at Kruger National Park in South Africa found that if rivers were degraded approximately $30 \%$ of tourism business would be lost (Turpie and Joubert 2001).

Most protected areas face decisions in trading off the environmental impacts of tourists versus the benefits that they bring in terms of revenue for park management, livelihoods for local people, and the health and cultural benefits for visitors. Fundamental for managing this trade-off is a decision as to what level of environmental impact is acceptable. IUCN has provided guidance on the full range of issues in managing visitors in protected areas (Spenceley and Goodwin 2007), and the Ramsar Convention has adopted guidance on managing tourism and recreation in wetlands (Ramsar 2012). Here we focus on the impacts of visitors on freshwater ecosystems.

Freshwater ecosystems are a major focus of visitor activities and in most PAs require trade-offs between freedoms of visitor use and biodiversity conservation (Hadwen, Boon et al. 2012). Riparian areas often provide a biodiverse corridor of moisture-loving vegetation running through drier regions, vegetation which creates its own moist micro-climate and habitat for many terrestrial species and the terrestrial life stages of aquatic species (e.g., insects). Fragmentation and trampling of this vegetation can significantly alter the freshwater ecosystem. For example, in the Wet Tropics World Heritage Area in Australia, visitor activities damaged riparian vegetation and reduced water quality at water holes used for swimming along the rivers (Turton 2005). Canoeing, kayaking and rafting may result in impacts along a river corridor, such as the impacts on wildlife and with pollution from human waste observed in the Ganga River gorge in India (Farooquee, Budal et al. 2008).

Sediment laden runoff from roads and tracks into water bodies can seriously harm aquatic biota, for example, by reducing filter feeding and prey visibility, and by smothering rocky substrates used for fish spawning and insect development (Pusey and Arthington 2003). The smallest 
'jump' up to or over a causeway or culvert across a waterbody may be a barrier to migration of aquatic species like fish and invertebrates, with implications for population exchange, recruitment and upstream-downstream biodiversity patterns (Olden 2016).

The IUCN recommends four generic strategies for reducing the impacts of large numbers of visitors (Spenceley and Goodwin 2007):

a) Supply of tourism or visitor opportunities, for instance, by having quotas for river rafting groups:

b) Demand for visitation, such as by limiting the length of stay or restricting more damaging activities like fishing;

c) Environment's capability of handling high use, for example, hardening sites with infrastructure like board walks;

d) Managing the impact of use, for instance, by requiring river rafting groups to carry away all their wastes or by distributing visitors over a broader area.

Key management responses for freshwater ecosystems should include: zoning land access, siting visitor facilities away from water bodies, fencing visitors out of riparian areas, creating hardened board walks and access points to the water, and regulating use of motorised vehicles and boating (Mosisch and Arthington 1998, Chatterjee, Phillips et al. 2008). Roads and tracks should be located to drain runoff away from water bodies and onto land (Sheridan and Noske 2007). Crossings should be built as bridges or broad culverts sunk into the stream bed so as to maintain passage for aquatic fauna. Avoiding contaminated discharge and treating sewage are particularly important in preventing pollution of water bodies. Toilet facilities should be sited well away from water bodies and provided with drainage facilities that avoid pollution of wetlands and lakes.

Pollution

Pollution of freshwater ecosystems in protected areas may originate externally or within a PA. Verhoeven (2014) advocates that wetland managers assess threats to water quality in the following four ways:

1. Determine the condition of wetlands in terms of water chemistry compared with least disturbed reference sites;

2. Establish the nutrient status of wetlands and try and establish the thresholds for nutrient loadings that, if exceeded, would lead to change in their structure and functioning;

3. Assess the capability of wetlands to remove or retain nutrients or sediments from through-flowing water without changing the ecological character of the wetland;

4. Evaluate the risk of wetlands receiving toxic substances, human pathogens or other hazardous materials from inflows.

The Ramsar Convention has adopted guidance on risk assessment and selection of early warning indicators that can be used to proactively manage pollution threats (Ramsar 1999). Earlier 
sections discussed management of the risks of cold, deoxygenated water releases from dams and other pollution from agriculture, aquaculture and recreational use. An upcoming chapter focusses on the importance of management at catchment scales, in part to reduce the threats from pollution generated from outside protected areas (Flitcroft, Little et al. 2017).

We now focus on management of other pollution threats arising within PAs. A particular challenge for freshwater PAs is the management of water quality for environmental flows, to ensure that water releases optimize ecological responses. For example, along the River Murray, attempts to use minimal volumes of environmental water to inundate large floodplain wetlands in warmer months can lead to anoxic 'blackwater' events that kill aquatic fauna (Howitt, Baldwin et al. 2007). Attempts to engineer freshwater PAs to conserve biodiversity with less water may end up exacerbating salinity (Pittock, Finlayson et al. 2012). Consequently, PA managers need to ensure that decisions on water management consider more than water volumes such that the water quality is adequate to sustain biota.

Conservation management requires use of chemicals such as fuels and herbicides that would have negative impacts if discharged into water bodies. Spills should be prevented wherever possible through good occupational health and safety practices, including siting chemicals away from water bodies, and securing and labelling stored chemicals. Potential pollutants should be stored and used on hard, internally draining surfaces that can contain accidental spills. Materials for soaking up any spills such as hay, sawdust or cat litter should be available on site, plus tools and bags for removing them for treatment. Spills into waterways require urgent advice to downstream authorities to close water diversions and prevent use of polluted water by people, wildlife and livestock wherever possible. Training of PA staff and development of pollution response plans for incident management are critical to ensure that spills are prevented where possible and well managed if they do occur (Worboys 2015). Erstwhile 'disasters' such as floods are inevitable such that freshwater PAs need to be managed to minimise the obvious risks of resulting pollution.

Wetlands and disasters

Floods, droughts and fire are natural processes in many freshwater ecosystems and plants and animals can normally tolerate or recover from them (Bond, Lake et al. 2008). In particular, many freshwater species and ecosystems are adapted to variability in water volumes and timing of flows and require variability to thrive, such that regulated water bodies should not be managed with un-natural, permanent or stable flows (Postel and Richter 2003). However, climate change may exacerbate the frequency and intensity of flood and drought events (Field and Van Aalst 2014), and has many adverse consequences for freshwater ecosystems and aquatic species. Adaptation options are considered further in the upcoming chapter on climate change (Finlayson and Pittock 2017). 
Some freshwater ecosystems are adapted to fire, such as floodplain forests in southern Australia, whereas others are destroyed and should be protected from fire, for example, peat swamp forests in Borneo. Riparian forests are often naturally fire resistant even where situated among other, flammable vegetation types. Traditional practices of local and Indigenous peoples of cool, patch burns around these ecosystems may conserve them from the effects of intense hot wildfires (Pittock, Finlayson et al. 2015).

A key question is whether wetland conservation can contribute to disaster risk reduction, a concept often described as ecosystem based conservation (UNEP 2012). Wetland conservation has been proposed as helping to mitigate the impacts of natural hazards such as dust and sand storms, floods, droughts, fires, landslides, coastal erosion, tsunamis, hurricanes, storms, and storm surges, and also accelerated sea level rise (Ramsar 2015). There are examples of wetland ecosystem restoration reducing the impacts of some natural hazards. For instance, restoration of floodplain wetlands is being used to provide room to hold and safely release flood peaks, such as along the Danube and Yangtze rivers (Ebert, Hulea et al. 2009, Yu, Jiang et al. 2009). Further, in South Africa, programs to remove invasive alien trees and restore eroding peat wetlands are increasing the base flow of rivers and streams (Le Maitre, van Wilgen et al. 2002, Gorgens and Wilgen 2004, Ellery, Grenfell et al. 2011).

However, other kinds of wetlands may not offer such benefits. In upland areas wetlands may promote rather than attenuate flood flows by raising groundwater levels, limiting water storage (Ramchunder, Brown et al. 2009, McCartney, Cai et al. 2013). For instance, some kinds of wetlands may increase evaporation and reduce downstream flows (Bullock and Acreman 2003). Consequently, different kinds of wetlands play different roles in the hydrological cycle. Freshwater PA managers need to assess how their wetlands may aid disaster risk reduction, establishing a case for broader societal support for conservation, or require a more nuanced approach to ensure recognition of their biodiversity conservation values while managing any disservices.

While this brief section on threats cannot detail all mitigation measures, the Ramsar Convention materials and guides for site managers (Chatterjee, Phillips et al. 2008, Ramsar 2011) are a valuable source of information for dealing with most threats and challenges to freshwater ecosystem conservation. Threats to particular aquatic ecosystems in PAs, and management options, are addressed in other chapters in this volume (Arthington, Finlayson et al. 2017, Finlayson, Davidson et al. 2017, Flitcroft, Little et al. 2017). In the next chapter we turn to conservation of freshwater species and protected area design options that involve mitigating threats and maximising biodiversity protection (Turak and Pittock 2017).

\section{Literature cited}

Abell, R., J. D. Allan and B. Lehner (2007). "Unlocking the potential of protected areas for freshwaters." Biological Conservation 134(1): 48-63. 
Allan, J. D., R. Abell, Z. E. B. Hogan, C. Revenga, B. W. Taylor, R. L. Welcomme and K. Winemiller (2005). "Overfishing of inland waters." BioScience 55(12): 1041-1051.

Arthington, A. H. (1996). "The effects of agricultural land use and cotton production on tributaries of the Darling River, Australia." GeoJournal 40(1-2): 115-125.

Arthington, A. H. and D. R. Blühdorn (1996). "The effects of species interactions resulting from aquaculture operations." Aquaculture and Water Resource Management.: 114-139.

Arthington, A. H., N. K. Dulvy, W. Gladstone and I. J. Winfield (2016). "Fish conservation in freshwater and marine realms: status, threats and management." Aquatic Conservation: Marine and Freshwater Ecosystems 26(5): 838-857.

Arthington, A.H., Roux, D., Nel, J., Rast, W., Finlayson, C.M., Froend, R., van Noekerk, L. and Turpie, J. (2017) 'Managing specific freshwater ecosystems'. In Finlayson, C.M., Arthington, A.H. and Pittock, J. (eds), Freshwater Ecosystems in Protected Areas: Conservation and Management. Taylor and Francis, Oxford, UK.

Arthington, A. H., J. Marshall, G. Rayment, H. Hunter and S. Bunn (1997). Potential impacts of sugarcane production on the riparian and freshwater environment. Intensive Sugar Cane Production: Meeting the Challenges Beyond 2000. B. A. Keating and J. R. Wilson. Wallingford, CAB International: 403-421.

AWS (2014). The AWS International Water Stewardship Standard. Edinburgh, Alliance for Water Stewardship.

Baird, I. G. (2006). "Probarbus jullieni and Probarbus labeamajor: The management and conservation of two of the largest fish species in the Mekong River in southern Laos." Aquatic conservation: marine and freshwater ecosystems 16(5): 517-532.

Baumgartner, L. J., N. K. Reynoldson, L. Cameron and J. G. Stanger (2009). "Effects of irrigation pumps on riverine fish." Fisheries Management and Ecology 16(6): 429-437.

Boelee, E., S. J. Scherr, P. L. Pert, J. Barron, M. Finlayson, K. Descheemaeker, J. C. Milder, R. Fleiner, S. Nguyen-Khoa, S. Barchiesi, S. W. Buntin, R. E. Tharme, E. Khaka, D. Coates, E. M. Solowey, G. J. Lloyd, D. Molden and S. Cook (2013). Management of water and agroecosystems in landscapes for sustainable food security. Managing Water and Agroecosysems for Food Security. E. Boelee. Wallingford, CAB International: 156-170.

Bond, N., P. Lake and A. Arthington (2008). "The impacts of drought on freshwater ecosystems: an Australian perspective." Hydrobiologia 600(1): 3-16.

Bostock, J., B. McAndrew, R. Richards, K. Jauncey, T. Telfer, K. Lorenzen, D. Little, L. Ross, N. Handisyde, I. Gatward and R. Corner (2010). "Aquaculture: global status and trends." Philosophical Transactions of the Royal Society of London B: Biological Sciences 365(1554): 2897-2912.

Bowman, M. B. (2002). "Legal perspectives on dam removal." BioScience 52(8): 739-747.

Brits, J., M. W. Van Rooyen and N. Van Rooyen (2002). "Ecological impact of large herbivores on the woody vegetation at selected watering points on the eastern basaltic soils in the Kruger National Park." African Journal of Ecology 40(1): 53-60.

Bruinsma, J. (2011). The resource outlook to 2050: By how much do land, water use and crop yields need to increase by 2050? Looking ahead in World Food and Agriculture: Perspectives to 2050. P. Conforti. Rome, FAO: 1-33.

Bullock, A. and M. Acreman (2003). "The role of wetlands in the hydrological cycle." Hydrology and Earth System Sciences Discussions 7(3): 358-389. 
Bush, S. R., B. Belton, D. Hall, P. Vandergeest, F. J. Murray, S. Ponte, P. Oosterveer, M. S. Islam, A. P. J. Mol, M. Hatanaka, F. Kruijssen, T. T. T. Ha, D. C. Little and R. Kusumawati (2013). "Certify Sustainable Aquaculture?" Science 341(6150): 1067-1068.

Canning-Clode, J. (2015). Biological Invasions in Changing Ecosystems. Warschau/Berlin, UNITED STATES, De Gruyter.

Canonico, G. C., A. Arthington, J. K. McCrary and M. L. Thieme (2005). "The effects of introduced tilapias on native biodiversity." Aquatic Conservation: Marine and Freshwater Ecosystems 15(5): 463-483.

Capon, S. J., A. J. J. Lynch, N. Bond, B. C. Chessman, J. Davis, N. Davidson, M. Finlayson, P. A. Gell, D. Hohnberg and C. Humphrey (2015). "Regime shifts, thresholds and multiple stable states in freshwater ecosystems; a critical appraisal of the evidence." Science of the Total Environment 534: 122-130.

Catford, J., R. Naiman, L. Chambers, J. Roberts, M. Douglas and P. Davies (2012). "Predicting Novel Riparian Ecosystems in a Changing Climate." Ecosystems 16(3): 382-400.

CBD (2002). COP 6 Decision VI/23 Alien species that threaten ecosystems, habitats or species. Monreal, Convention on Biological Diversity.

Chatterjee, A., B. Phillips and D. Stroud (2008). Wetland management planning. A guide for site managers. WWF, Wetlands International, IUCN and Ramsar Convention. India.

Cooke, S. J., R. Arlinghaus, B. M. Johnson and I. G. Cowx (2015). Recreational fisheries in inland waters. Freshwater Fisheries Ecology. J. F. Craig, Wiley Blackwell: 449-465.

Cooke, S. J. and I. G. Cowx (2006). "Contrasting recreational and commercial fishing: searching for common issues to promote unified conservation of fisheries resources and aquatic environments." Biological Conservation 128(1): 93-108.

Cooke, S. J., C. D. Suski, R. Arlinghaus and A. J. Danylchuk (2013). "Voluntary institutions and behaviours as alternatives to formal regulations in recreational fisheries management." Fish and Fisheries 14(4): 439-457.

Cotter, D., V. O'Donovan, N. O'Maoiléidigh, G. Rogan, N. Roche and N. P. Wilkins (2000). "An evaluation of the use of triploid Atlantic salmon (Salmo salar L.) in minimising the impact of escaped farmed salmon on wild populations." Aquaculture 186(1): 61-75.

Daufresne, M. and P. Boet (2007). "Climate change impacts on structure and diversity of fish communities in rivers." Global Change Biology 13(12): 2467-2478.

Davies, P. E., J. H. Harris, T. J. Hillman and K. F. Walker (2010). "The Sustainable Rivers Audit: assessing river ecosystem health in the Murray-Darling Basin, Australia." Marine and Freshwater Research 61(7): 764-777.

Davis, J., A. P. O'Grady, A. Dale, A. H. Arthington, P. A. Gell, P. D. Driver, N. Bond, M. Casanova, M. Finlayson and R. J. Watts (2015). "When trends intersect: The challenge of protecting freshwater ecosystems under multiple land use and hydrological intensification scenarios." Science of the Total Environment 534: 65-78.

de Fraiture, C., D. Wichelns, J. Rockstrom, E. Kemp-Benedict, N. Eriyagama, L. J. Gordon, M. A. Hanjra, J. Hoogeveen, A. Huber-Lee and L. Karlberg (2007). Looking ahead to 2050: scenarios of alternative investment approaches. Water for food, water for life: a Comprehensive Assessment of Water Management in Agriculture. D. Molden. London, UK: Earthscan; Colombo, Sri Lanka, International Water Management Institute (IWMI): 91-145. Diana, J. S. (2009). "Aquaculture production and biodiversity conservation." Bioscience 59(1): 27-38. 
Dixon, A., A. Wood, M. Finlayson and G. E. van Halsema (2008). Exploring agriculture wetland interactions: a framework for analysis. Scoping agriculture -wetland interaction: towards a sustainable multiple-response strategy. A. Wood and G. E. van Halsema. Rome, FAO. FAO Water Report 33: 5-27.

Döll, P. (2002). "Impact of climate change and variability on irrigation requirements: a global perspective." Climatic change 54(3): 269-293.

Dudgeon, D., A. H. Arthington, M. O. Gessner, Z. I. Kawabata, D. J. Knowler, C. Lévêque, R. J. Naiman, A. H. Prieur-Richard, D. Soto, M. L. Stiassny and C. A. Sullivan (2006). "Freshwater biodiversity: importance, threats, status and conservation challenges." Biological reviews 81(2): 163-182.

Dudley, N., Ed. (2013). Guidelines for applying protected area management categories. Gland, International Union for the Conservation of Nature.

Ebert, S., O. Hulea and D. Strobel (2009). "Floodplain restoration along the Lower Danube: a climate change adaptation case study." Climate and Development 1(3): 212-219.

Ellery, W., M. Grenfell, S. Grenfell, D. Kotze, T. McCarthy, S. Tooth, P. Grundling, H. Beckedahl, D. 1. Maitre and L. Ramsay (2011). "WET-origins: controls on the distribution and dynamics of wetlands in South Africa." WRC Report(334/09).

Ellis, E. C. (2011). "Anthropogenic transformation of the terrestrial biosphere." Philosophical Transactions of the Royal Society of London A: Mathematical, Physical and Engineering Sciences 369(1938): 1010-1035.

Esselman, P. C. and J. Allan (2011). "Application of species distribution models and conservation planning software to the design of a reserve network for the riverine fishes of northeastern Mesoamerica." Freshwater Biology 56(1): 71-88.

Falkenmark, M., C. M. Finlayson and L. Gordon (2007). Agriculture, water, and ecosystems: avoiding the costs of going too far. Water for food, water for life: A comprehensive assessment of water management in agriculture. M. D. London, Earthscan: 234-277.

Farooquee, N. A., T. K. Budal and R. Maikhuri (2008). "Environmental and socio-cultural impacts of river rafting and camping on Ganga in Uttarakhand Himalaya." Current Science Bangalore 94(5): 587.

Fausch, K. D., C. E. Torgersen, C. V. Baxter and H. W. Li (2002). "Landscapes to riverscapes: Bridging the gap between research and conservation of stream fishes: A continuous view of the river is needed to understand how processes interacting among scales set the context for stream fishes and their habitat." BioScience 52(6): 483-498.

Field, C. and M. Van Aalst (2014). Climate change 2014: impacts, adaptation, and vulnerability, IPCC.

Finlayson, C. M. (2013). "Climate change and the wise use of wetlands: information from Australian wetlands." Hydrobiologia 708(1): 145-152.

Finlayson, C. M., S. J. Capon, D. Rissik, J. Pittock, G. Fisk, N. C. Davidson, K. A. Bodmin, P. Papas, H. A. Robertson, M. Schallenberg, N. Saintilan, K. Edyvane and G. Bino (2017). "Policy considerations for managing wetlands under a changing climate." Marine and Freshwater

Research: -.

Finlayson, C. M., N. Davidson, D. Pritchard, G. R. Milton and H. MacKay (2011). "The Ramsar Convention and Ecosystem-Based Approaches to the Wise Use and Sustainable Development of Wetlands." Journal of International Wildlife Law \& Policy 14(3-4): 176-198.

Finlayson, C. M., N. C. Davidson, P. A. Gell, R. Kumar and R. J. McInnes (2017). Managing freshwater protected areas in the global landscape. Freshwater Ecosystems in Protected Areas: 
Conservation and Management. C. M. Finlayson, A. H. Arthington and J. Pittock. Oxford, Taylor and Francis.

Finlayson, C. M. and J. Pittock (2017). Climate change and the management of freshwater protected areas. Freshwater Ecosystems in Protected Areas: Conservation and Management. C. M. Finlayson, A. H. Arthington and J. Pittock. Oxford, Taylor and Francis.

Flitcroft, R. L., C. Little, J. Cabrera and I. Arismendi (2017). Planning ecologically: the importance of management at catchment scales. Freshwater Ecosystems in Protected Areas: Conservation and Management. C. M. Finlayson, A. H. Arthington and J. Pittock. Oxford, Taylor and Francis.

Forbes, J. P., R. J. Watts, W. A. Robinson, L. J. Baumgartner, M. S. Allen, P. McGuffie, L. Cameron and D. A. Crook (2015). "System-specific variability in Murray cod and golden perch maturation and growth influences fisheries management options." North American Journal of Fisheries Management 35(6): 1226-1238.

Ghassemi, F. and I. White (2007). Inter-basin water transfer: case studies from Australia, United States, Canada, China and India. Cambridge, Cambridge University Press.

Gordon, L. J., C. M. Finlayson and M. Falkenmark (2010). "Managing water in agriculture for food production and other ecosystem services." Agricultural Water Management 97(4): 512-519. Gorgens, A. H. M. and B. W. Wilgen (2004). "Invasive alien plants and water resources in South Africa: current understanding, predictive ability and research challenges." South African Journal of Science 100(1): 27-33.

Gozlan, R. E., J. R. Britton, I. Cowx and G. H. Copp (2010). "Current knowledge on non-native freshwater fish introductions." Journal of fish biology 76(4): 751-786.

Hadwen, W. L., P. I. Boon and A. H. Arthington (2012). "Aquatic ecosystems in inland Australia: tourism and recreational significance, ecological impacts and imperatives for management." Marine and freshwater research 63(4): 325-340.

Hortle, K. G. (2007). "Consumption and the yield of fish and other aquatic animals from the lower Mekong basin." MRC Technical Paper 16: 1-88.

Horwitz, P. and C. M. Finlayson (2011). "Wetlands as settings: Ecosystem services and health impact assessment for wetland and water resource management." BioScience in press.

Howard, B. C. (2012). "Salmon re-enter Olympic National Park river thanks to Elwha Dam removal." National Geographic NewsWatch [online].

Howitt, J. A., D. S. Baldwin, G. N. Rees and J. L. Williams (2007). "Modelling blackwater: Predicting water quality during flooding of lowland river forests." Ecological Modelling 203(34): 229-242.

ICEM (2010). MRC Strategic Environmental Assessment (SEA) of hydropower on the Mekong mainstream: Final report. Hanoi, International Center for Environmental Management.

IHA (2010). Hydropower Sustainability Assessment Protocol. Sutton, International Hydropower Association.

Krchnak, K., B. Richter and G. Thomas (2009). Integrating environmental flows into hydropower dam planning, design, and operations. Washington DC, World Bank Group. Le Maitre, D. C., B. W. van Wilgen, C. M. Gelderblom, C. Bailey, R. A. Chapman and J. A. Nel (2002). "Invasive alien trees and water resources in South Africa: case studies of the costs and benefits of management." Forest Ecology and Management 160(1-3): 143-159.

Lin, C. K. and Y. Yi (2003). "Minimizing environmental impacts of freshwater aquaculture and reuse of pond effluents and mud." Aquaculture 226(1): 57-68. 
Lindloff, S. (2000). "Dam removal: A citizen's guide to restoring rivers." River Alliance of Wisconsin.

Mapes, L. V. (2016). Elwha: Roaring back to life. The Seattle Times. Seattle, The Seattle Times: [online].

McCartney, M., X. Cai and V. Smakhtin (2013). Evaluating the flow regulating functions of natural ecosystems in the Zambezi River Basin. Colombo, International Water Management Institute. IWMI Research Report 148.

McCrary, J. K., E. P. van den Berghe, K. R. McKaye and L. J. Lopez Perez (2001). "Tilapia cultivation: a threat to native fish species in Nicaragua." Encuentro 58: 3-19.

McGinnity, P., P. Prodöhl, A. Ferguson, R. Hynes, N. Maoiléidigh, N. Baker, D. Cotter, B. O'Hea, D. Cooke, G. Rogan and J. Taggart (2003). "Fitness reduction and potential extinction of wild populations of Atlantic salmon, Salmo salar, as a result of interactions with escaped farm salmon." Proceedings of the Royal Society of London B: Biological Sciences 270(1532): 24432450.

MEA (2005). (Millennium Ecosystem Assessment), Ecosystems and human well-being: wetlands and water synthesis. Washington DC, World Resources Institute.

Millennium Ecosystem Assessment (2005). A framework for assessment. Island Press, Washington, DC.

Mosisch, T. D. and A. H. Arthington (1998). "The impacts of power boating and water skiing on lakes and reservoirs." Lakes \& Reservoirs: Research \& Management 3(1): 1-17.

MRC (2010). Basin-wide rapid sustainability assessment tool. Vientiene, Mekong River Commission.

Nagabhatla, N., R. Wickramasuriya, N. Prasad and C. M. Finlayson (2010). "A multi-scale geospatial study of wetlands distribution and agricultural zones, and the case of India." Tropical Conservation Science 3(3): 344-360.

Naylor, R. L., R. J. Goldburg, J. H. Primavera, N. Kautsky, M. C. Beveridge, J. Clay, C. Folke, J. Lubchenco, H. Mooney and M. Troell (2000). "Effect of aquaculture on world fish supplies." Nature 405(6790): 1017-1024.

Naylor, R. L., S. L. Williams and D. R. Strong (2001). "Aquaculture - A gateway for exotic species." Science 294(5547): 1655-1656.

New South Wales Department of Primary Industries (2008). "The NSW Hatchery Quality Assurance Scheme.".

Olden, J. D. (2016). Challenges and opportunities for fish conservation in dam-impacted waters. Cambridge, Cambridge University Press.

Panayotou, T. (1982). "Management concepts for small-scale fisheries: economic and social aspects." FAO.

Pauly, D., V. Christensen, S. Guenette, T. J. Pitcher, U. R. Sumaila, C. J. Walters, R. Watson and D. Zeller (2002). "Towards sustainability in world fisheries." Nature 418(6898): 689-695.

Pelicice, F. M., J. R. S. Vitule, D. P. Lima Junior, M. L. Orsi and A. A. Agostinho (2014). "A serious new threat to Brazilian freshwater ecosystems: the naturalization of nonnative fish by decree." Conservation Letters 7(1): 55-60.

Pittock, J. and C. M. Finlayson (2011). "Australia's Murray-Darling Basin: freshwater ecosystem conservation options in an era of climate change." Marine and Freshwater Research 62: 232-243. Pittock, J., C. M. Finlayson and J. A. Howitt (2012). "Beguiling and risky: "Environmental works and measures" for wetlands conservation under a changing climate." Hydrobiologia 708(1): 111-131. 
Pittock, J., M. Finlayson, A. H. Arthington, D. Roux, J. H. Matthews, H. Biggs, I. Harrison, E. Blom, R. Flitcroft, R. Froend, V. Hermoso, W. Junk, R. Kumar, S. Linke, J. Nel, C. Nunes da Cunha, A. Pattnaik, S. Pollard, W. Rast, M. Thieme, E. Turak, J. Turpie, L. van Niekerk, D. Willems and J. Viers (2015). Managing freshwater, river, wetland and estuarine protected areas. Protected area governance and management. G. L. Worboys, M. Lockwood, A. Kothari, S. Feary and I. Pulsford. Canberra, ANU Press: 569-608.

Pittock, J. and J. Hartmann (2011). "Taking a second look: climate change, periodic re-licensing and better management of old dams." Marine and Freshwater Research 62: 312-320.

Pittock, J. and J. Hartmann (2011). "Taking a second look: climate change, periodic relicensing and improved management of dams." Marine and Freshwater Research 62(3): 312-320.

Poff, N. L., J. D. Allan, M. B. Bain, J. R. Karr, K. L. Prestegaard, B. D. Richter, R. E. Sparks and J. C. Stromberg (1997). "The natural flow regime." BioScience 47(11): 769-784.

Postel, S. and B. Richter (2003). Rivers for life: managing water for people and nature. Washington DC, Island Press.

Pusey, B. J. and A. H. Arthington (2003). "Importance of the riparian zone to the conservation and management of freshwater fish: a review." Marine and Freshwater Research 54(1): 1-16. Pyke, G. H. (2008). "Plague minnow or mosquito fish? A review of the biology and impacts of introduced Gambusia species." Annual Review of Ecology, Evolution, and Systematics 39: 171191.

Rahel, F. J., B. Bierwagen and Y. Taniguchi (2008). "Managing aquatic species of conservation concern in the face of climate change and invasive species." Conservation Biology 22(3): 551561.

Ramchunder, S., L. Brown and J. Holden (2009). "Environmental effects of drainage, drainblocking and prescribed vegetation burning in UK upland peatlands." Progress in Physical Geography 33(1): 49-79.

Ramsar (1999). Resolution VII.10 Wetlands risk assessment framework. Gland, Ramsar Convention on Wetlands.

Ramsar (2002). Resolution VIII:18 Invasive species and wetlands. Gland, Ramsar Convention. Ramsar (2011). The Ramsar handbooks for the wise use of wetlands, 4th edition. Gland, Ramsar Convention on Wetlands.

Ramsar (2012). Resolution XI.7 Tourism, recreation and wetlands. Gland, Ramsar Convention. Ramsar (2015). Resolution XII:13 Wetlands and disaster risk reduction. Gland, Ramsar Convention.

Ramsar Convention Secretariat (2010). Ramsar handbooks for the wise use of wetlands, Gland: Ramsar Convention Secretariat.

Rebelo, L.-M., C. M. Finlayson and N. Nagabhatla (2009). "Remote sensing and GIS for wetland inventory, mapping and change analysis." Journal of environmental management 90(7): 21442153.

Rebelo, L.-M., M. P. McCartney and C. M. Finlayson (2010). "Wetlands of Sub-Saharan Africa: distribution and contribution of agriculture to livelihoods." Wetlands Ecology and Management 18(5): 557-572.

Righter, R. W. (2005). The battle over Hetch Hetchy: America's most controversial dam and the birth of modern environmentalism, Oxford University Press.

Rolls, R. J., I. O. Growns, T. A. Khan, G. G. Wilson, T. L. Ellison, A. Prior and C. C. Waring (2013). "Fish recruitment in rivers with modified discharge depends on the interacting effects of flow and thermal regimes." Freshwater Biology 58(9): 1804-1819. 
Schlaepfer, M. A., D. F. Sax and J. D. Olden (2011). "The potential conservation value of nonnative species." Conservation Biology 25(3): 428-437.

Schloesser, D. W. and T. F. Nalepa (1994). "Dramatic decline of unionid bivalves in offshore waters of western Lake Erie after infestation by the zebra mussel, Dreissena polymorpha." Canadian Journal of Fisheries and Aquatic Sciences 51(10): 2234-2242.

Schlosser, I. J. and P. L. Angermeier (1995). "Spatial variation in demographic processes in lotic fishes: Conceptual models, empirical evidence, and implications for conservation." American Fisheries Society Symposium 17: 360-370.

Sheridan, G. J. and P. J. Noske (2007). "A quantitative study of sediment delivery and stream pollution from different forest road types." Hydrological Processes 21(3): 387-398.

Spenceley, A. and H. Goodwin (2007). "Nature-Based Tourism and Poverty Alleviation: Impacts of Private Sector and Parastatal Enterprises In and Around Kruger National Park, South Africa." Current Issues in Tourism 10(2-3): 255-277.

Strayer, D. L. (2010). "Alien species in fresh waters: ecological effects, interactions with other stressors, and prospects for the future." Freshwater biology 55(s1): 152-174.

Sullivan, M. G. (2002). "Illegal angling harvest of walleyes protected by length limits in Alberta." North American Journal of Fisheries Management 22(3): 1053-1063.

Tacon, A. G. and M. Metian (2008). "Global overview on the use of fish meal and fish oil in industrially compounded aquafeeds: Trends and future prospects." Aquaculture 285(1): 146-158. Tidwell, J. H. and G. L. Allan (2001). "Fish as food: aquaculture's contribution." EMBO reports 2(11): 958-963.

Turak, E. and J. Pittock (2017). Conserving freshwater species in protected areas. Freshwater Ecosystems in Protected Areas: Conservation and Management. C. M. Finlayson, A. H.

Arthington and J. Pittock. Oxford, Taylor and Francis.

Turpie, J. and A. Joubert (2001). "Estimating potential impacts of a change in river quality on the tourism value of Kruger National Park : an application of travel cost, contingent, and conjoint valuation methods." WaterSA 27(3): 387-398.

Turton, S. M. (2005). "Managing environmental impacts of recreation and tourism in rainforests of the wet tropics of Queensland World Heritage Area." Geographical Research 43(2): 140-151.

UNEP (2012). Ecosystem-based adaptation guideance: Moving from principles to practice.

Working document April 2012. Nairobi, UN Environment Programme.

UNWTO (2016). UNWTO Tourism Highlights 2016 Edition. Madrid, UN World Tourism Organisation.

Verhoeven, J. T. A. (2014). "Water-quality issues in Ramsar wetlands." Marine and Freshwater

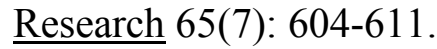

Vilà, M. and P. E. Hulme, Eds. (2017). Impact of Biological Invasions on Ecosystem Services. Invading Nature - Springer Series in Invasion Ecology. Basel, Springer International Publishing. Vitule, J. R. S., C. A. Freire, D. P. Vazquez, M. A. Nuñez and D. Simberloff (2012). "Revisiting the potential conservation value of non-native species." Conservation Biology 26(6): 1153.

Vörösmarty, C. J., P. B. McIntyre, M. O. Gessner, D. Dudgeon, A. Prusevich, P. Green, S. Glidden, S. E. Bunn, C. A. Sullivan, C. R. Liermann and P. M. Davies (2010). "Global threats to human water security and river biodiversity." Nature 467(7315): 555-561.

WCD (2000). Dams and development: a new framework for decision-making. The report of the World Commission on Dams. London, Earthscan. 
Weber, E. D. and K. D. Fausch (2003). " Interactions between hatchery and wild salmonids in streams: differences in biology and evidence for competition." Canadian Journal of Fisheries and Aquatic Sciences 60(8): 1018-1036.

Winemiller, K., P. McIntyre, L. Castello, E. Fluet-Chouinard, T. Giarrizzo, S. Nam, I. Baird, W. Darwall, N. Lujan and I. Harrison (2016). "Balancing hydropower and biodiversity in the Amazon, Congo, and Mekong." Science 351(6269): 128-129.

Worboys, G. L. (2015). Managing incidents. Protected Areas Governance and Management. G. L. Worboys, M. Lockwood, A. Kothari, S. Feary and I. Pulsford. Canberra, ANU Press: 823850.

Yu, X., L. Jiang, J. Wang, L. Wang, G. Lei and J. Pittock (2009). "Freshwater management and climate change adaptation: experiences from the central Yangtze in China." Climate and Development 1(3): 241-248.

Zarfl, C., A. E. Lumsdon, J. Berlekamp, L. Tydecks and K. Tockner (2015). "A global boom in hydropower dam construction." Aquatic Sciences 77(1): 161-170. 